\title{
Determination of selected properties and fracture toughness of HVOF coatings
}

\section{Stanovenie vybraných vlastností a lomovej húževnatosti HVOF povlakov}

Landová M., Brezinová J.

Technical University in Košice

E-mail: mariana.landova@tuke.sk

The article is aimed at evaluation of chosen properties of thermally sprayed coatings based on tungsten carbide. It was evaluated two types of coatings - WC-FeCrAl and WC-WB-Co. The coatings were deposited on basic material steel AISI $316 \mathrm{~L}$. The aim of experimental works was to determine the quality and resistance of coatings in corrosion environment depending on number of thermal cycles. The quality of coatings was evaluated by determination of their adhesion depending on thermal cycles, determination of microhardness and indentation fracture toughness. Coatings were exposed in tribo-corrosion conditions with the presence of $1 \% \mathrm{NaCl}$. The results of experimental showed a higher quality of coating WC-WB-Co.

\section{INTRODUCTION}

New green carbides for better both health and safety protection at work, is compared with powders containing cobalt matrix and hard carbides WC-Co a WC-Co-Cr. They have been developed with different chemical composition, size of carbides and for different methods of production. This powders have wide application in many fields of industry because of their wear resistance, erosion and corrosion protection [1,2,3].

Recently, improvement of HVOF (high velocity oxygen fuel) technology allows replacement of chromic coatings and creates high-quality surfaces. Coatings applied using HVOF technology are more ecology, cleaner and cheaper compared with hard chromium coating. Besides, experiments have shown that these coatings exhibit very good fatigue properties. Unlike chromium plating the size of coated part is not limited. In comparison with other processes of spraying, high velocity flame allows creating smooth surface and high stiffness coatings $[4,8,9,11]$.

Coatings applied by HVOF technology have found wide use in automotive industry, aviation, chemical, textile and mining industry like full replacement for hard chrome coatings. Coatings are used for example in area of engineering construction, where hydraulic equipments
Príspevok rieši problematiku zameranú na hodnotenie vybraných vlastností žiarovostriekaných povlakov na báze karbidu volfrámu. Hodnotené boli dva druhy povlakov - WC-FeCrAl a WC-WB-Co. Povlaky boli nanesené na základný materiál ocel' AISI 316L. Ciel'om experimentálnych prác bolo stanovit' kvalitu a odolnost' povlakov v koróznom prostredi v závislosti na počte teplných cyklov. Kvalita povlakov bola hodnotená stanovením ich adhézie $v$ závislosti od tepelných cyklov, stanovením mikrotvrdosti a indentačnej lomovej húževnatosti. Povlaky boli vystavené v tribo-koróznych podmienkach s prítomnostou $1 \% \mathrm{NaCl}$. Výsledky experimentov poukázali na vyššiu kvalitu povlaku WC-WB-Co.

are exposed to heavy loading and corrosion. Examples of their application: globe valves, hydraulic cylinders of marine machines, pivot pins, chemical reactors, drill press and many others $[1,4,6,7]$.

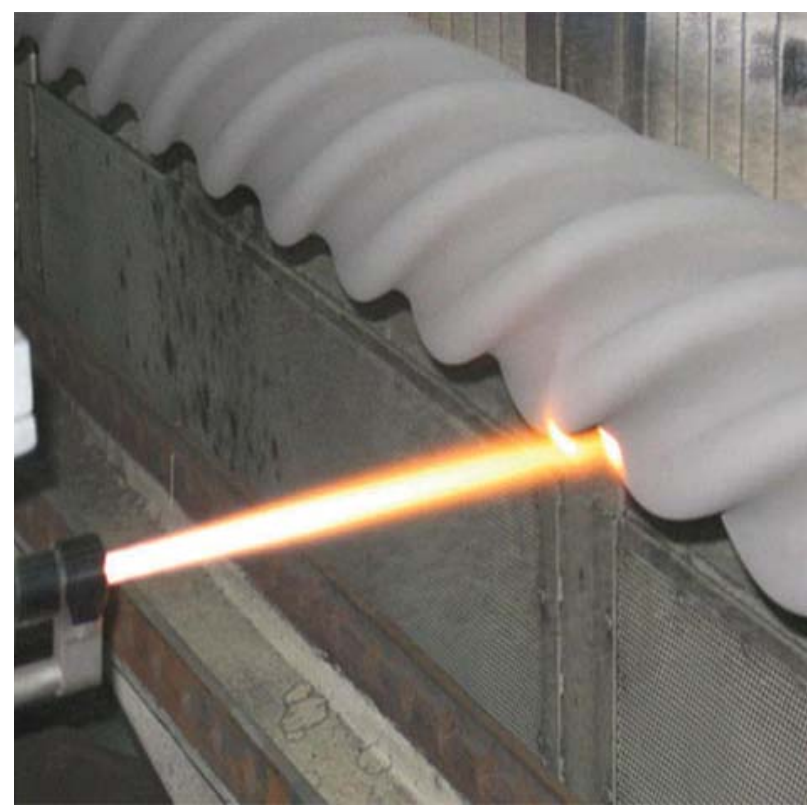

Fig. 1. Application of HVOF technology in practice Obr. 1. Aplikácia HVOF technológie v praxi 
Evaluation of indentation fracture toughness of thermal spraying coatings has its meaning especially in case of materials resistant to wear. Along with toughness, Young's modulus and Poisson ratio characterizes ability of materials to resist stress which is the cause of their wear. Given the structure of thermally sprayed coatings, the fracture toughness is different from bulk material of the same composition. Their value depends on the degree of porosity, the presence of oxides and also on the size and shape distribution of the reinforcing hard particles. Lamellar structure of coatings causes their strong anisotropy and higher resistance to crack propagation $[5,10,12,13]$.

Presented article deals with the evaluation of wear of coatings based on WC-WB-Co and WC-FeCrAl.

\section{MATERIALS AND METHODS}

Evaluated coatings were applied by the HVOF technology on base material - steel AISI 316L, whose chemical composition is shown in Tab. 1.

The test pieces were of cylindrical shape with dimensions of $\varnothing 25 \times 5 \mathrm{~mm}$ suitable for evaluating the adhesion, fracture toughness, microhardness, thickness and adhesive wear of the coatings. Pretreatment of the base material was made by blasting technology using pneumatic blast equipment with blasting pressure of 0.4 $\mathrm{MPa}$, the distance between the nozzle and the sample was $300 \mathrm{~mm}$ and the impact angle of abrasive material was $90^{\circ}$. Used blasting abrasive medium was white corundum F22 with a grain size of $0.56 \mathrm{~mm}$. Application device for spraying of coating was PRAXAIR Tafa JP

Tab. 1. The chemical composition of the base material (wt.\%) / Chemické zloženie základného materiálu ( $\mathrm{hm} . \%)$

\begin{tabular}{|c|c|c|c|c|c|c|c|c|}
\hline $\mathbf{C}$ & $\mathbf{S i}$ & $\mathbf{M n}$ & $\mathbf{P}$ & $\mathbf{S}$ & $\mathbf{C r}$ & $\mathbf{M o}$ & $\mathbf{N i}$ & $\mathbf{F e}$ \\
\hline 0.03 & 1 & 2 & 0.04 & 0.03 & $16.5-18.5$ & $2-2.5$ & $10.5-13.5$ & bal. \\
\hline
\end{tabular}

Tab. 2. Spraying parameters / Parametre nástriku

\begin{tabular}{|l|c|}
\hline Nozzle diameter & $25.4 \mathrm{~mm}$ \\
\hline Kerosene flow rate & $6.0 \mathrm{~g} \mathrm{~h}^{-1} / 22,7 \mathrm{~h} \mathrm{~h}^{-1}$ \\
\hline Oxygen flow rate & $8001 \mathrm{~min}^{-1}$ \\
\hline Powder feed rate & $75 \mathrm{~g} \mathrm{~min}^{-1}$ \\
\hline Standoff distance & $380 \mathrm{~mm}$ \\
\hline
\end{tabular}

5000 with the system HP/HVOF and HVOF System Powder Feeder. Spraying parameters are shown in Tab.2.

After application of coating, samples were subjected to thermal cyclic loading in the electric furnace chamber. The actual cycle consisted of heating the samples to $600^{\circ} \mathrm{C}$ and holding this temperature for $10 \mathrm{~min}$ followed by cooling in air to ambient temperature. The test samples were exposed to 5 and 10 thermal cycles. Designation of samples: WC-FeCrAl after five thermal cycles $\mathrm{WC}-\mathrm{FeCrAl} / 5$, after ten thermal cycles $\mathrm{WC}-\mathrm{FeCrAl} / 10$, for coating WC-WB-Co after five thermal cycles WCWB-Co/5 and after ten cycles WC-WB-Co/10.

Two types of powders were applied on the base material: WC-FeCrAl, which belongs to group "green carbides", and a reference powder WC-WB-Co. Their chemical composition is listed in Tab. 3.

Coating WC-FeCrAl is environmentally friendly without emission of elements $\mathrm{Co}$ and $\mathrm{Ni}$. This coating is characterized by very good resistance to erosion and corrosion in sea water, in the environment with neutral and high $\mathrm{pH}$, and good resistance to cavitation.

The thickness of the coatings was evaluated on the cross section using optical microscope according to STN EN ISO 9220, structure of coating was studied by means of SEM. Thickness of coatings was determined using the QuickPHOTO CAMERA 2.3.

Measurement of microhardness of assessed coatings was carried out according to EN ISO 4516. The measurement was realized on cross-section of samples using HMV-2 Micro Hardness Tester SHIMADZU using HV 0.1 scale. Loading force was $980.7 \mathrm{~N}$ (100 g), holding time was 15 seconds.

The adhesion of thermally sprayed coatings was determined according to EN 582. The principle of destructive mechanical test consists of detachment of applied coating from the base material using tensile test machine. The test samples with dimensions of $\varnothing 25 \times 50 \mathrm{~mm}$ were adhesively connected to the counterpart using adhesive Loctite 9497. It is a two-component adhesive of medium viscosity and cures at room temperature. It is characterized by high compressive and tensile strength.

Adhesive wear of coatings was evaluated by pinon-disc method using tribometer. This method was used to determine the friction coefficient. The evaluation of investigated coatings was in accordance with ISO 20808: 2004. As a counterpart, tungsten carbide ball was used. The test was made in two different environments, the dry friction in atmosphere and in the corrosive environment of $1 \% \mathrm{NaCl}$ solution (next only $\mathrm{NaCl}$ ).

Tab. 3. Chemical composition of coatings (wt.\%) / Chemické zloženie povlakov (hm.\%)

\begin{tabular}{|c|c|c|c|c|c|c|c|}
\hline & C & Fe & Cr & Al & WC & WB & Co \\
\hline WC-FeCrAl & $5.4-5.9$ & $10-12$ & $2.5-3.8$ & $0.6-1.2$ & $77.1-81$ & - & - \\
\hline WC-WB-Co & - & - & - & - & 60 & 30 & 10 \\
\hline
\end{tabular}


Indentation fracture toughness of the samples was also evaluated using metallographic cross-sections. Indentation tests were performed with Vickers indenter and the loading forces were $10 \mathrm{~N}$ for coating WC-FeCrAl and $30 \mathrm{~N}$ for coating WC-WB-Co. Size of the imprint and crack length were evaluated by using a digital microscope Keyence VHX 5000. The values of indentation fracture toughness were determined using the relationships described in Tab. $4[13,14]$.

Tab. 4. Computational models of indentation fracture toughness, where: $\mathrm{L}-$ loading, $\mathrm{c}-$ the sum of the crack length and half the diagonal indentation, $\mathrm{a}-$ half of indentation, $1=\mathrm{c}-\mathrm{a}-$ crack length, E - modulus of elasticity, HV - Vickers hardness [14] / Modely výpočtu indentačnej lomovej húževnatosti, kde: L - sila zat'aženia , c - súčet dľ̌ky trhliny a polovice uhlopriečky vtlačku, $a$-polovica vtlačku, $l=c-a-$ dĺžka trhliny, $E-m o-$ dul pružnosti v t'ahu, HV-tvrdost' podl'a Vickersa

\begin{tabular}{|l|l|c|}
\hline $\begin{array}{l}\text { Computational models of } \\
\text { indentation fracture toughness }\end{array}$ & Condition & Name \\
\hline $\mathrm{K}_{\mathrm{c}}=0.0101 \mathrm{~L} /\left(\mathrm{ac}^{1 / 2}\right)$ & & $\mathrm{LS}$ \\
\hline $\mathrm{K}_{\mathrm{c}}=0.0515 \mathrm{~L} /\left(\mathrm{ac}^{3 / 2}\right)$ & & $\mathrm{LF}$ \\
\hline $\mathrm{K}_{\mathrm{c}}=0.079 \mathrm{~L} /\left(\mathrm{ac}^{3 / 2}\right) \log (4,5 \mathrm{a} / \mathrm{c})$ & $0.6<1 / \mathrm{a}>4.5$ & $\mathrm{EW}$ \\
\hline $\mathrm{K}_{\mathrm{c}}=0.0824 \mathrm{~L} / \mathrm{c}^{3 / 2}$ & & $\mathrm{EC}$ \\
\hline $\mathrm{K}_{\mathrm{c}}=0.0319 \mathrm{~L}\left(\mathrm{al}^{1 / 2}\right)$ & & $\mathrm{SWMC}$ \\
\hline
\end{tabular}

\section{RESULTS}

Quality, resistance and tribological properties of the coatings were determined by a given load condition on the basis of the methodology mentioned above.

The thickness of the coating ranged from 134.2 to $159.7 \mu \mathrm{m}$ (Fig. 2).

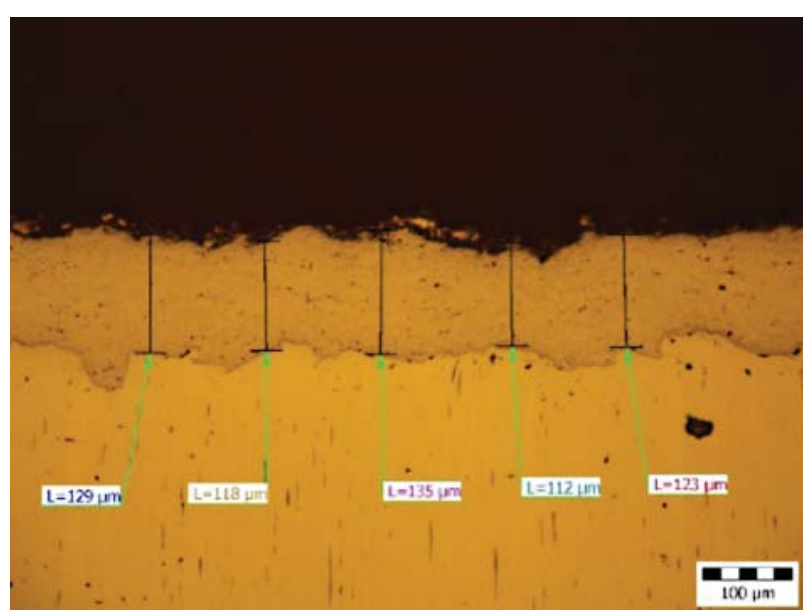

a) WC-WB-Co
Fig. 3 shows the microstructure, which was further used for the evaluation of coatings. When comparing the internal structure of coatings, the coating WC-WB-Co was less porous and reached a more compact structure in contrast to the WC-FeCrAl coating, in which small
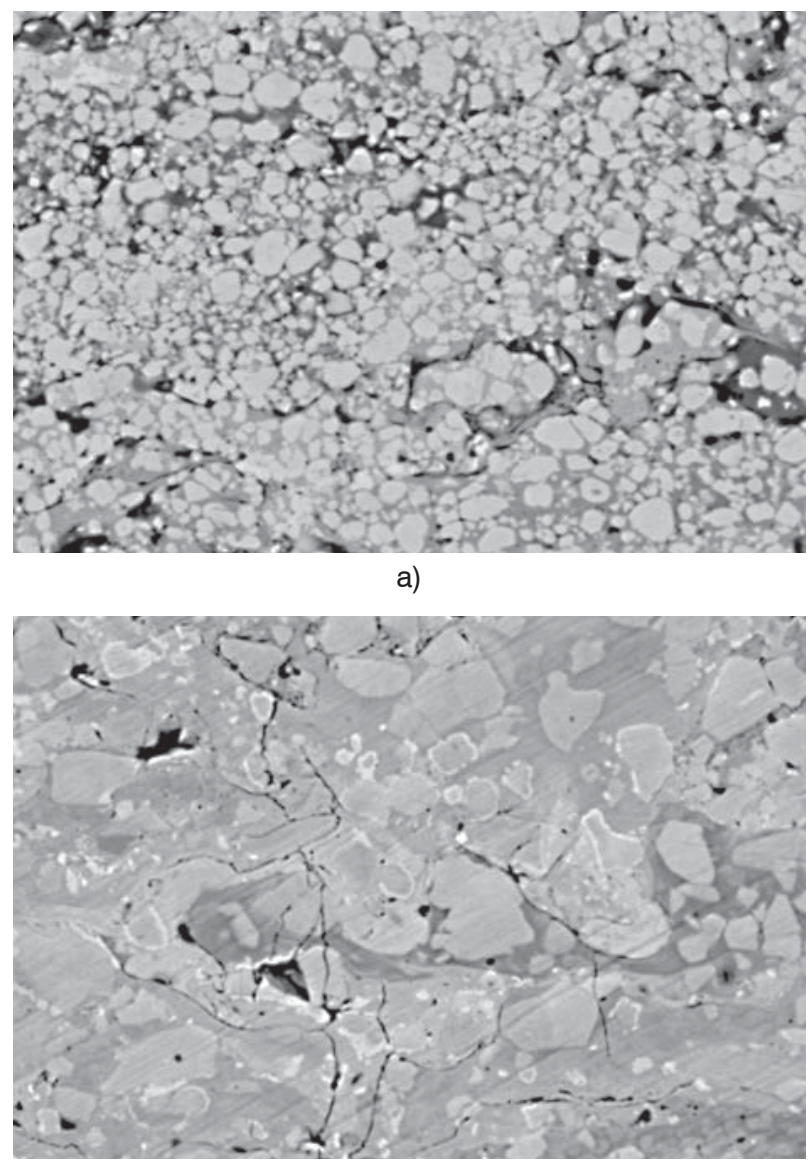

b)

Fig. 3. The microstructure of the coatings (SEM) Obr. 3. Mikroštruktúra hodnotených povlakov (SEM)

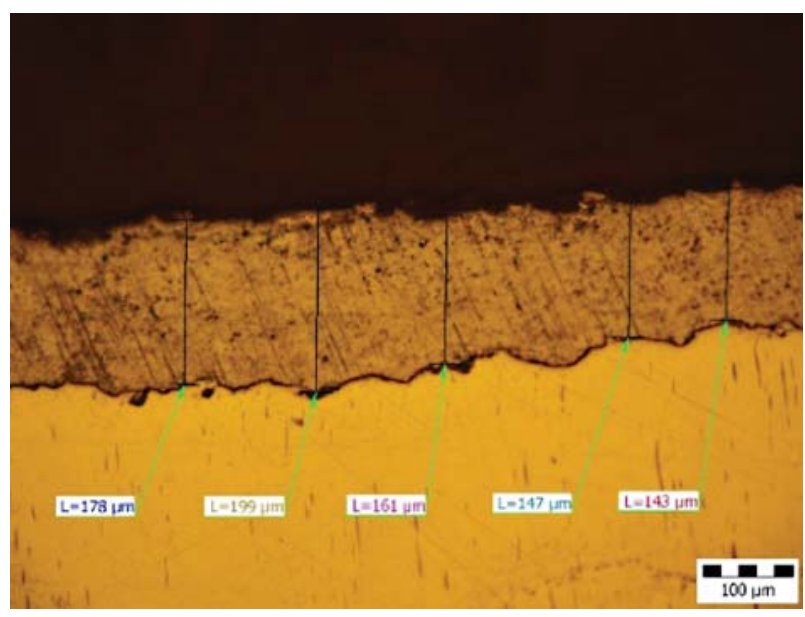

b) WC-FeCrAI

Fig. 2. Measurement of thickness of coatings WC-WB-Co (a) a WC-FeCrAl (b) Obr. 2. Meranie hrúbky povlakov WC-WBCo (a) a WC-FeCrAl (b) 
pores were observed. Despite the smaller number of pores, they can act as stress raisers for creation of cracks and thereby contribute to decreasing the quality of the coating.

The course of hardness of coatings in dependence on the number of thermal cycles is shown in Fig. 4.

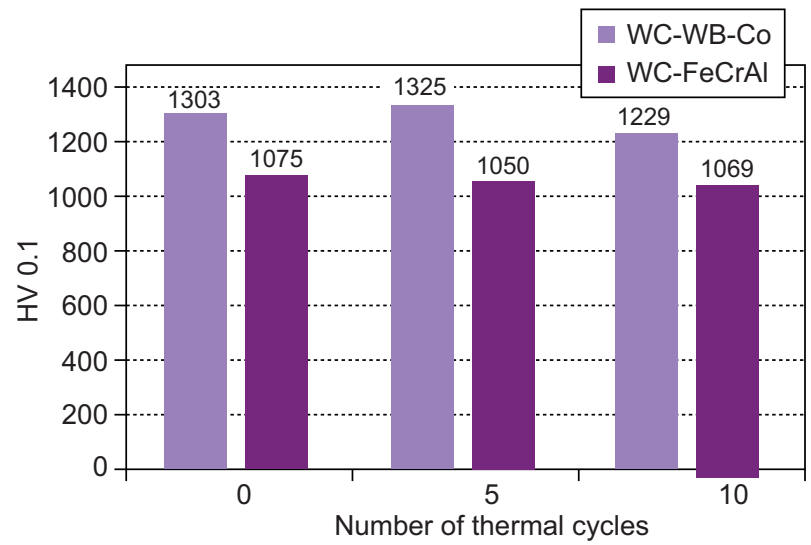

Fig. 4. The microhardness of coatings Obr. 4. Mikrotvrdost' povlakov

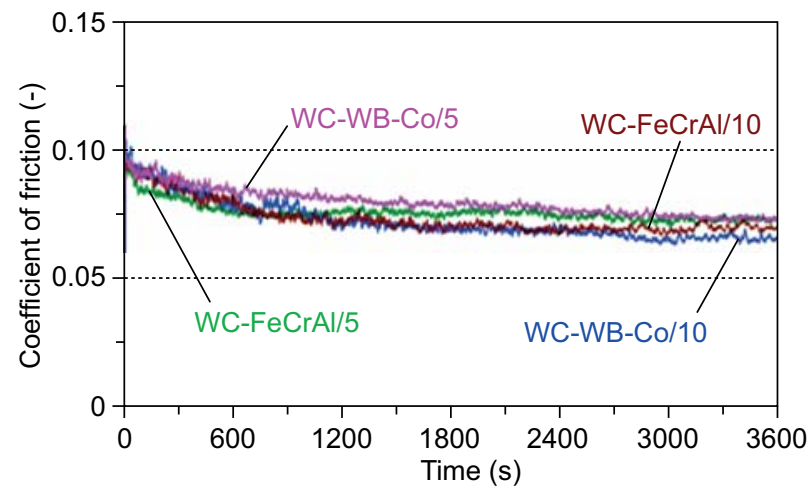

Fig. 5. The course of the friction coefficient in the corrosive environment of $1 \% \mathrm{NaCl}$

Obr. 5. Priebeh koeficientu trenia v koróznom prostredí 1\% $\mathrm{NaCl}$

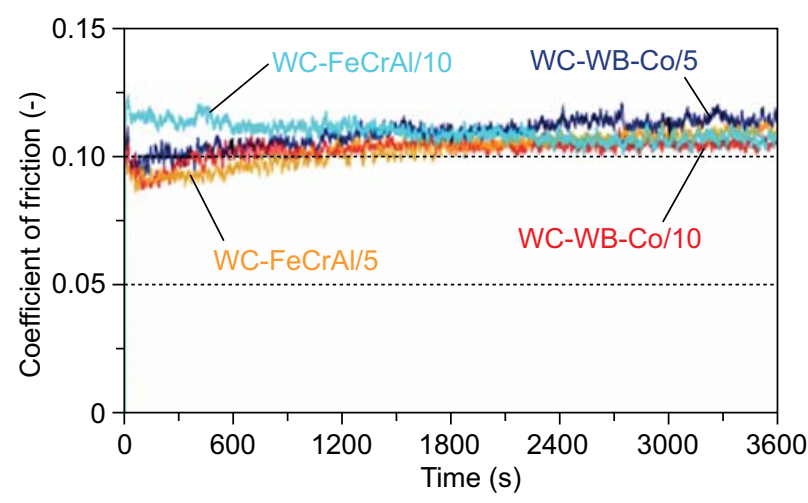

Fig. 6. The course of the friction coefficient in the dry sliding Obr. 6. Priebeh koeficientu trenia v prostredí ATM
Based on the measured values of microhardness of coatings it can be stated that these coatings are suitable for use in conditions of thermal cyclic loading, given that microhardness of the coatings due to thermal cyclic loading did not change significantly. Higher values of microhardness were measured on coating WC-WB-Co.

The adhesion of the coating could not be established, because detachment occurred always in adhesive. Neither cohesive failure in coating nor adhesive failure between coating and substrate was observed. The failure of adhesive occurred always between $47 \mathrm{MPa}$ to $56 \mathrm{MPa}$, we can say that adhesion of coatings exceeded mentioned values.

Based on the above methodology,adhesive wear of coatings was evaluated. After running-in friction coefficient became stable. Values of friction coefficient were higher in conditions of dry sliding in comparison with sliding in $\mathrm{NaCl}$ solution. Fig. 5 and Fig. 6 show the course of the friction coefficient depending on time.

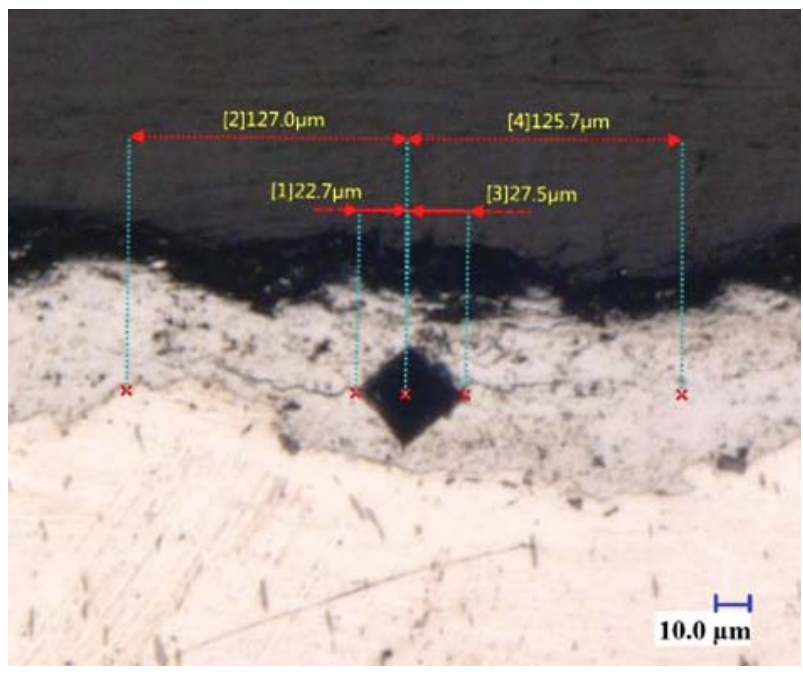

Fig. 7. Imprint in coating WC-FeCrAl

Obr. 7. Vpich indentora do povlaku WC-FeCrAl

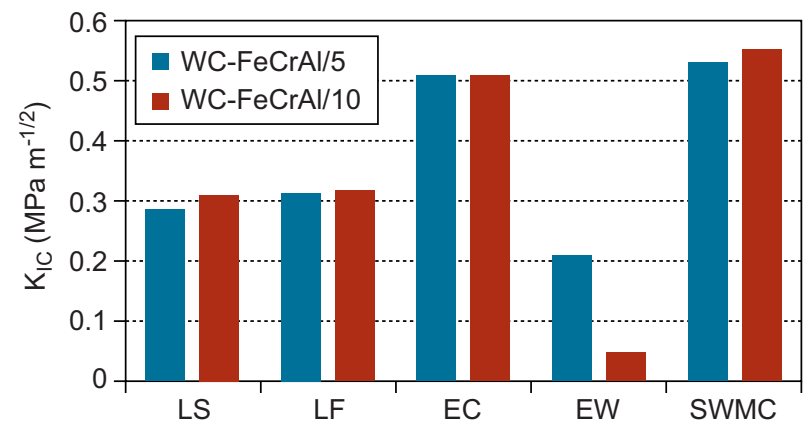

Fig. 8. $\mathrm{K}_{\mathrm{IC}}$ for coating WC-FeCrAl according to several calculation models

Obr. 8. KIC pre povlak WC-FeCrAl podla niekolkých výpočtových modelov 
Higher value of friction coefficient was recorded when dry sliding. Effect of thermal cyclic stress on the value of the friction coefficient has not been markedly shown.

Fig. 7 shows an imprint into the coating WC-FeCrAl. The measured values of cracks spread parallel with coating surface are input values for calculation and determination of the indentation fracture toughness $\mathrm{K}_{\mathrm{IC}}$. Set of suitable mathematical models (LS, LF, EW, EC and SWMC) was used for determination the indentation fracture toughness $\mathrm{K}_{\mathrm{IC}}$. Selected models have been designed on the basis of the conditions and criteria to be followed by evaluating the $\mathrm{K}_{\mathrm{IC}}$.

Fig. 8 shows the results of $\mathrm{K}_{\mathrm{IC}}$ of the coating WC$\mathrm{FeCrAl}$ after 5 and 10 thermal cycles depending on the used model for calculation of $\mathrm{K}_{\mathrm{IC}}$. In the case of coating $\mathrm{WC}-\mathrm{FeCrAl} / 0$, no cracks from the corners of the imprint were visible, so the fracture toughness of the coating has not been evaluated - coating without thermal loading showed the best resistance to crack propagation.

From the results obtained it can be stated the thermal load of the coating directly impairs its resistance to crack propagation. The most suitable models for the

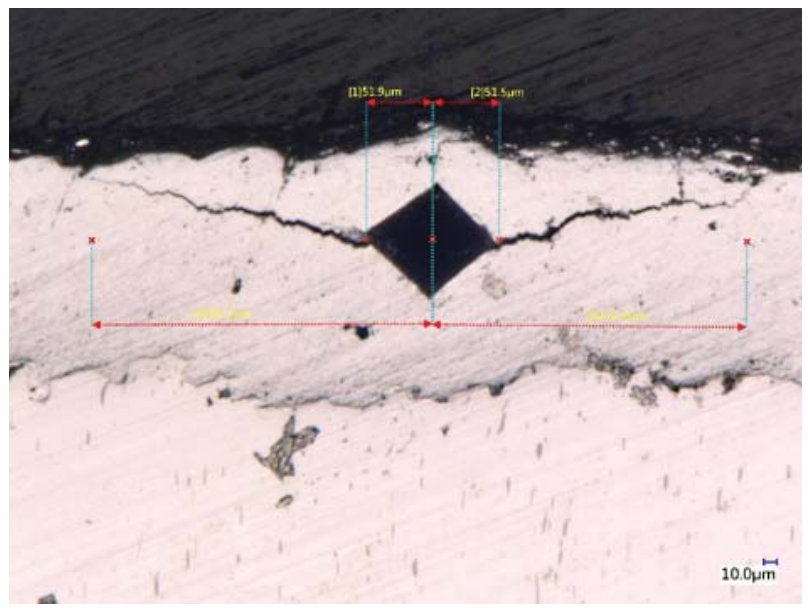

Fig. 9. Imprint in coating WC-WB-Co

Obr. 9. Vpich indentora do povlaku WC-WB-Co

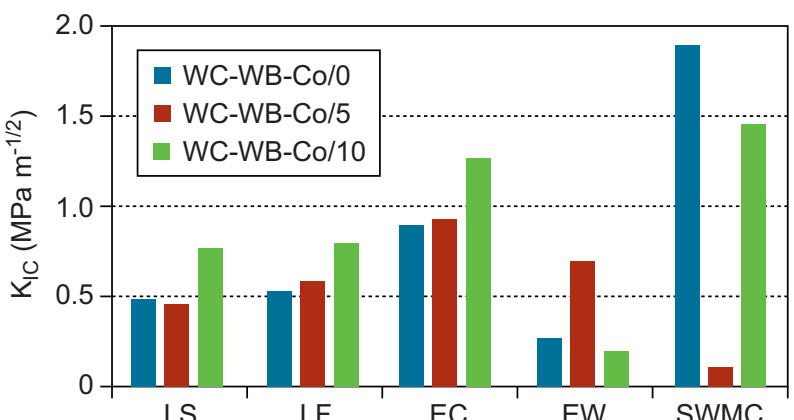

Fig. 10. $\mathrm{K}_{\mathrm{IC}}$ for coating WC-WB-Co according to several calculation models

Obr. 10. $K_{I C}$ pre povlak WC-WB-Co podla niekolkých výpočtových modelov calculations seem to be the EC model to determine the resistance to radial cracks and the SWMC model to determine the resistance to Palmqvist cracks. These models showed the smallest variation in the calculation.

Fig. 9 shows an imprint into the coating WC-WBCo. Coating WC-WB-Co has more homogeneous structure and at measurement it showed higher hardness. At small load were not disseminate any cracks from corners of imprint and therefore was used more load force to $30 \mathrm{~N}$.

The results in Fig. 10 show that the cyclic thermal stress worsens the crack propagation resistance of coating WC-WB-Co. The most suitable models for the calculations were the same as in previous case (EC and SWMC). These models show the smallest variation when calculating.

\section{CONCLUSION}

The presented article deals with the evaluation of the coatings applied by high velocity oxygen-fuel technology. As a reference WC-FeCrAl coating was chosen, which belongs to the green carbides and was compared to WC-WB-Co coating.

Coatings WC-FeCrAl and WC-WB-Co are suitable for use in the extremely mechanically and thermally loaded environments. They are characterized by good wear resistance and they are able to resist the erosive and abrasive wear.

The aim of the experimental work was to verify the chosen properties of the evaluated thermal spraying coatings.

The thickness of the coatings ranged from 134.2 to $159.7 \mu \mathrm{m}$. Higher values of micro hardness were measured on coating WC-WB-Co. Effect of thermal cyclic loading on change of microhardness of coatings has not been markedly proved.

The adhesion of coatings both thermally unloaded and loaded exceeded $47 \mathrm{MPa}$. Adhesion pull-off test was limited by cohesion of the adhesive.

The higher values of friction coefficient were measured in the case of dry friction for both coatings in compared with friction in $\mathrm{NaCl}$ solution.Different course of friction coefficient was recorded in corrosive environments. Effect of temperature cycles on the friction coefficient has not been markedly proved in both exposed environments.

The coating WC-WB-Co exhibited a higher resistance to crack propagation. From the measured values of microhardness it can be stated that the coating WC-WB-Co is harder and tougher. It is caused by the chemical composition of the coating which contains a large amount of carbide components.

For the possibilities of using HVOF coatings of the green carbides group it is necessary to carry out a further set of experiments. 


\section{Acknowledgement}

The article is the result of the grant project VEGA 1/0600/13 - Research and development of advanced composite coatings and films for innovation engineering products, KEGA 059TUKE-4/2016-Innovative learning approaches in the composite component's design and production area, and APVV SK-UA-2013-0013 - Investigation of cracking and wear laws of materials for metallurgical equipment.

\section{REFERENCES}

1. Bolelli G. et al. Cermet coatings with Fe-based matrix as alternative to $\mathrm{WC}-\mathrm{CoCr}$ : Mechanical and tribological behaviours. Surface and Coatings Technology 2012, 206 (19), 4079-4094.

2. Sahraouia T. HVOF sprayed WC-Co coatings: Microstructure, mechanical properties and friction moment prediction, Materials \& Design 2010, 31, 1431-1437.

3. Mingheng L., Panagiotis D., Computational study of particle in-flight behavior in the HVOF thermal spray process. Chemical Engineering Science 2006, 61, 6540-6552.

4. Landová M., Brezinová J., Guzanová A. Experimentálne hodnotenie adhézneho opotrebenia povlakov na báze $W C-F e C r A l$, Novus Scientia:Košice, 105-109, 2016. ISBN 978-80-553-2495-1

5. Murthya J.K.N. Effect of grinding on the erosion behaviour of a WC-Co-Cr coating deposited by HVOF and detonation gun spray processes, Wear 2001, 294, 592-600.
6. Sahraouia T. et al. HVOF sprayed WC-Co coatings: Microstructure, mechanical properties and friction moment prediction, Materials \& Design 2010, 31, 1431-1437.

7. Żórawski W. The microstructure and tribological properties of liquid-fuel HVOF sprayed nanostructured WC-12Co coatings, Surface and Coatings Technology 2013, 220, 276-281.

8. Landová M. et al. Diagnostics of degradation of surfaces treated by thermal spraying. In-service damage of materials, its diagnostics and prediction. Ternopil': TNTU Ternopil', 2015, 70-73. ISBN 978-966-305-073-7

9. Wood R.J.K., Tribology of thermal sprayed WC-Co coatings, International Journal of Refractory Metals and Hard Materials 2010, 28, 82-94.

10. Guzanová A. et al. Study of Selected Properties of Coatings Devoted to Extreme Tribo-Corrosive Conditions, Materials Science Forum 2015, 32-36.

11. Kumar R.K. et al. Effect of Spray Particle Velocity on Cavitation Erosion Resistance Characteristics of HVOF and HVAF Processed 86WC-10Co4Cr Hydro Turbine Coatings, Journal of Thermal Spray Technology 2016, $1-14$.

12. Bolelli G. et al. Properties of WC-FeCrAl coatings manufactured by different high velocity thermal spray processes, Surface and Coatings Technology 2014, 25 74-89.

13. Houdková $\breve{S}$. et al. Effect of Heat Treatment on the Microstructure and Properties of HVOF-Sprayed Co-Cr-W Coating, Journal of Thermal Spray Technology 2016, 25, 546-557.

14. Houdková Š. et al. Indentační lomová houževnatost’ žárových nástřiků, Sborník konference Lokální mechanické vlastnosti 2006, 70-78. 